\title{
Developing Learning Media of Cirebonese Language
}

\author{
Ahmad Ripai ${ }^{*}$, Basuki Wibawa ${ }^{*}$, Asmaniar Z Idris \\ Jakarta State of University \\ *Corresponding author: ahmadripai_tp10s3@mahasiswa.unj.ac.id, bwibawa@unj.ac.id \\ Received July 08, 2018; Revised August 12, 2018; Accepted September 26, 2018
}

\begin{abstract}
This study employs the research and development model of Borg \& Gall and Dick \& Carey involving students of SMPN 4 Kota Cirebon. This study aims to develop Cirebonese language learning media for the junior high school of the eleventh-grade students. To find out the results of the content of media, instructional design and instructional media experts validation were conducted. In addition, individual, group, and field try out were conducted.The data regarding the quality of the product were collected through questionnaire then analyzed by using descriptive analysis of qualitative and quantitative descriptive analysis. The try-out process involved the experts of Cirebonese language media and instructional design. It also involved six students an individual (one to one) try out, fifteen students for group and thirty-four students for the field try out.The results showed, first, because t, 3,0569E18 or $=3.0569 \times 10-18$ or $=.000000000000030596$ smaller than $t$ table at a significance level $(\alpha)$ amounted to 2.034515 0.05, then it rejects Ho and accepts Ha. It can be concluded that the Cirebonese language learning using developed instructional media is effective in improving students' learning outcomes. Second, the mean scores after using the media of Cirebonese language learning showed higher (better) than before using learning media of Cirebonese language. It is shown in the table Paired Sample Statistics, where the mean score before using media language learning Cirebon amounted 50.44117647 while the mean score after using learning media of Cirebonese language amounted 65.88235294. This means that learning media of Cirebonese language has a positive effect. Third, because the learning media of Cirebonese language had a positive influence, so that the decision to develop a program learning media Cirebonese language ensures to have practical significance.
\end{abstract}

Keywords: development, learning media, Cirebonese language

Cite This Article: Ahmad Ripai, Basuki Wibawa, and Asmaniar Z Idris, "Developing Learning Media of Cirebonese Language." American Journal of Educational Research, vol. 6, no. 9 (2018): 1301-1305. doi: 10.12691/education-6-9-9.

\section{Introduction}

Information technology in recent years have grown very rapidly, thus changing the paradigm of the community in seeking and obtaining the information is no longer limited to information newspapers, audio-visual and electronic, but also sources of other information on them through the Internet. The influence of the development of information and communication technologies in the learning process is marked by the emergence of a variety of educational media from simple educational media, development of instructional media to internet-based learning. The development of instructional technology in education promises great potential for changing the way a person to learn, to obtain information, to customize information and others.

Learning media also provides an opportunity for educators to develop learning techniques so as to get maximum results. For instance, for students, the use of learning media is expected to make them easier to get the information because they do not reach from merely the textbook. The ability of instructional media technology has developed rapidly and will further add to the ease in getting information for the sake of learning. In learning activities, teachers are often encountered with abstract material and beyond the everyday experience of students. As a consequence, teachers get some difficulties to provide some teaching material and students get some problems to understand. Visualization is one way that can be done to make something abstract to be real. Images the two-dimensional or three-dimensional model is a visualization that is often used in the learning process. Visualization in the learning process develops in the form of moving images (animation) that can be added to the sound (audio). Serving audio-visual or better known as the learning media is expected to make the visualization more attractive.

Edgar Dale in Heinrich Robert et al. described the importance of visualization and verbalist learning experience called "Edgar Dale Cone experience". According to Edgar Dale in [1] that there is a continuum from the concrete to the abstract between direct experience, visual and verbal in instilling a concept or understanding. The more concrete experiences will be better to ensure the learning process. Thus, that visualization is easier for people to grasp the understanding.

Cirebon language lesson, which is the local content subjects in the learning process still face many obstacles. 
For instances, teachers have not met in accordance with the required qualifications and competencies, lack of learning tools that support unavailability of teaching media. Other factors are the lack of interest of students in learning Cirebonese language and inadequate allocation of instructional time also hindered the learning process a Cirebonese language lesson. These obstacles are very influential in the language learning process and results of Cirebon. The effort to facilitate the Cirebonese language learning process using media has prompted researchers to develop instructional media for this subject.

\section{Learning Media}

Media (plural) is derived from the Latin word which is the form (singular) medium meaning "in between" (between). Media is in the middle between the sender of the message (sender) and the recipient (receiver, audience or communicant). Sadiman et al., defined that the media restrictions, namely: everything that can be used to deliver the message (message) from the sender to the recipient so that it can stimulate the mind, feelings, concerns and interests of students in a way that learning occurs [2].

Essentially, a learning process is a communication process, delivering a message of introduction to the receiver. Messages with content/teaching poured into symbols of communication, both verbal (word and writing) and nonverbal is called encoding. The interpretation of the symbols of the communication by the students is called decoding. This interpretation sometimes does not get success or failure. The failure to understand what is heard, read, seen or observed, caused by disorders that become an obstacle in the communication process known as barriers or noise. The more abstract understanding of verbal is increasingly accepted. Thus, what are the functions of the media?

The diagram cone of learning from Edgar Dale clearly gives the emphasis to the importance of media in education [1]. Generally, the media can function as follows:

- to clarify the message that is not to verbalise.

- to overcome the limitations of space, time, energy and resources senses.

- to provide potential passion to learn, the more direct interaction between students with learning resources.

- to allow children to learn independently according to their talents and abilities of visual, auditory and kinesthetic.

- to provide the same stimuli, similar experience and to rise to the same perception.

\section{Multimedia}

Multimedia comes from the word multi and media, multi is derived from the Latin (nouns) meaning a lot or mixed. The word media comes from the Latin media, the medium which means the intermediary or something that is used to deliver, convey or carry something, [3]. Multimedia is a combination of computer and video (Rosch, in Famukhit, et al, [4]) or multimedia is a tool that can create a dynamic and interactive presentations, that the combine text, graphics, animation, audio and videoand image video (Robin and Linda, in Famukhit, et al, [4]). Tay Vaughan [5], defines the multimedia is a combination of various media texts, images, video, music or handwritten. For the computer, the information for, all prepared from digital data. Oblinger in Munir [3], defines the multimedia represents the union of two or more communication media such as text, graphics, animation, audio and video with the characteristics of computer interactivity to generate the attractive presentation. Meanwhile, Mayer believes that using a multimedia presentation of material can directly use both of the words and pictures at the same time. The definition of 'words' here is the material presented in the form of verbal or verbal form, for example using text words printed or uttered. What is meant by 'image' is the material presented in pictorial form or shape of the image, can be in the form of static graphics (illustrations, graphs, photos and maps), or use dynamic charts (animation and video [6].

According to Plomp \& Ely multimedia is described as a dynamic process of transformation of technologies to develop and to progress in making the understanding, and its name changes from years to years such as interactive video, interactive media, the combination of media, hypermedia and multimedia. Multimedia packaged as a product uses more than one medium as a communications tool, for example, text, images, movies, sound, graphics and animation in various combinations. They are integrated for use with computers that make it easier to interact [7].

\section{Methods}

This research adopts the development of research known Research and Development (R \& D). Research and development in education is a process to develop and validate a product of education including material objects and procedures such as media, methods and learning models. In accordance with this definition, this research seeks to produce effective and interactive learning media. This research and development are carried out with reference to the model of research and development formulated by, Borg \& Gall which has been adapted from the steps of instructional design Dick and Carey. These steps are called by Borg \& Gall as The Step of the System Approach Model of Educational Research and Development (R \& D) (1983: 569-571) which includes the steps as follows: 1) identify instructional goal(s), 2) conduct instructional analysis, 3) analyze learners and context, 4) write performance objective, 5) develop assessment instrument, 6) develop instructional strategies, 7) develop and select materials /instructional media, 8) Design and implement formative evaluation of instruction, 9) revise instructional activities, 10) design and implement summative evaluation.

These steps are illustrated in the figure below: 


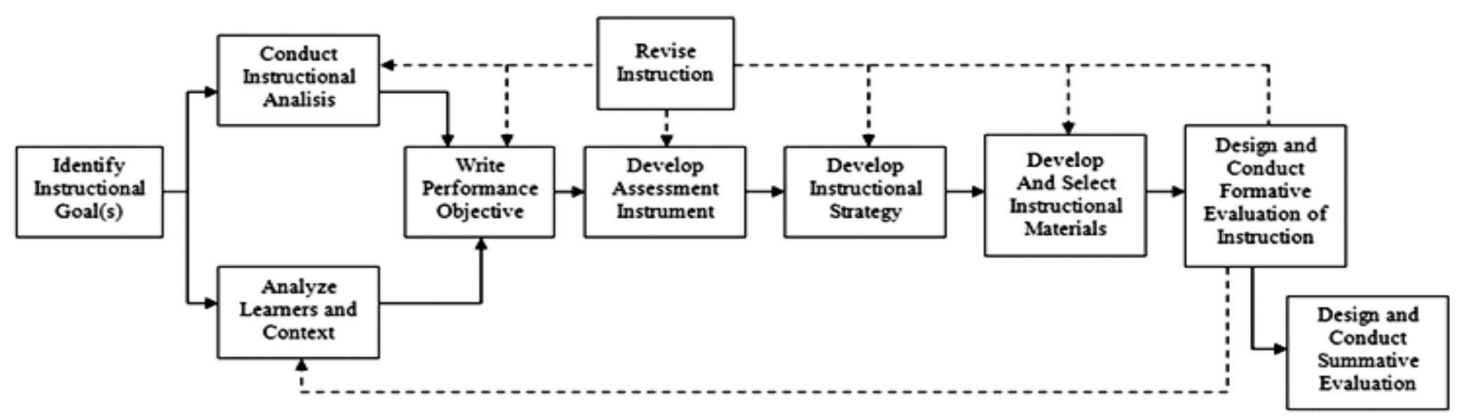

Figure 1. The Step of the System Approach Model of Educational Research and Development

\section{Development Planning}

In designing and developing learning media of Cirebonese language, it consists of a conceptual model design, procedural models and physical models. In the conceptual model in this research is based on the design of learning media. The design of this learning media is produced based on the principles of development models which refer to theoretical studies, and analytical results and needs.

Procedural model employed Dick \& Carey's development design which consists of three main stages of the systems approach a) identifying the stages; $b$ ) developing stage, c) the stage of evaluating and revising [8].

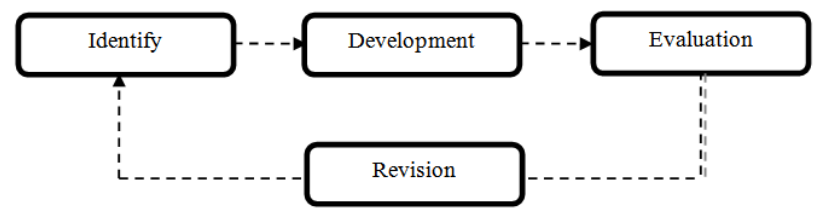

Figure 2. Chart Systems Approach

\section{Validation, Evaluation and Revised Media}

\subsection{Identification Phase}

The steps undertaken in the phases identify:

a) Identify the instructional needs

b) Analyze instructional objectives

c) Identify the behavior/goals and characteristics of students.

\subsection{Developing Phase}

The steps to be taken in developing stage are:

a) Formulating Instructional Objectives.

b) Developing Assessment Instruments.

c) Developing Instructional Strategies.

d) Developing Materials / Instructional Learning Media., the first step in this phase is to develop learning media for Cirebonese language subjects. $\mathrm{CD}$ media for Cirebonese language learning. The results of developed materials / media can be the initial products of this learning media of Cirebonese subject.

Validation performed in this study is a formative evaluation stage, namely:

\subsection{Specialist/expert Validation}

Experts validation is conducted to obtain information about the suitability of the material with the learning objective, the concept of truth, the latest material, as well as the scope and depth of the material. In this research, expert validation is conducted by a Cirebonese language expert, media specialists, and instructional design experts.

\subsection{Test A-One (One to One)}

Evaluation of one to one (1-1) is committed to measuring six students who have the capability of high, medium and low. At this stage, the evaluation is done to get information about the readability of the material, the focus of the material and attractiveness of the product.

\subsection{Trial for Small Group (Small Group Try-out)}

Evaluation is conducted on small groups involving eight to twelve students. Learning is done like a real situation, but with a fewer number of students. At this stage, the evaluation was the same as the evaluation of one to one in order to get information on student feedback about the legibility of the material, the material focus and attractiveness of the product. The difference from the previous one is on the instrument used in the form of questionnaires, whereas in this stage the evaluation instrument used is one to one interviews.

\subsection{Field Trial (Field Try-out)}

Field trials involve large groups which are equivalent to the real target. In this final phase, the evaluation is conducted to obtain comprehensive information about the quality and effectiveness of interactive media for Cirebonese language learning products. Field trials were conducted in class IX students of SMPN 4 cities Cirebon.

\section{Feasibility Media (Theoretical and Empirical)}

\subsection{The Result of Experts Review}

The expert's review aims to get information about the suitability of the material with the learning objectives, the 
concept of truth, the latest material, as well as the scope and depth of the material.

Content Experts, subject matter experts evaluate the content materials of developed multimedia products. The evaluation is the delivery of pre-activities, learning objectives, goals of the content, depth of the material, the student's tasks, exercises and the competency test. the validator of subject matters experts consisted of two people: namely: Supali Kasim, S.Pd., M.Pd (the first book author of Cerbon-Dermayu, Disdik West Java), and Liliek Kurniati, S.Pdi (Cirebonese language teachers SMPN 4 Kota Cirebon).

Multimedia Experts, instructional media experts evaluate the appearance of the developed product. The evaluation is the use of colour combinations background /text, typical of media, layout, consistency slide, menu/feature bar, navigation buttons, and practicality of multimedia. the validator of instructional media experts consisted of two people namely: Dr Widyo Nugroho, M. Pd, (Head of Audio-visual centre Gunadarma University), and Saluki, M.Kom, (Lecturer of Computer Science and Head of Data and Information of IAIN Syekh Nurjati Cirebon).

Instructional Design Experts, instructional design experts evaluate the learning media products from the aspect of learning activity sequence of the developed product. The evaluation aims to see media, learning activities with the media, the steps of procedural activities, and compliance learning objectives with examples of questions, about assignments, exercises and evaluation questions. Validator instructional design consists of two people namely: Dr Rusmono, M.Pd (Lecturer of Design Instruction UNJ PPS), and $\mathrm{Dr} \mathrm{Hj}$. Nurlaela, M.Ag, (Lecturer of IAIN Sheikh Nurjati Cirebon). Based on the results of a review and expert assessment, Cirebonese language learning media developed by the researchers is considered as the first prototype. However, there are still shortcomings that must be rectified and improved. Therefore, the experts concluded that this learning media is eligible to proceed to the next trial with expert suggested revisions.

\subsection{Evaluation of One to One}

The results of a revised prototype 1 produce prototype2, as a reference for the evaluation of one to one. The evaluation phase one to one (1-1) or prototype 2 is conducted in Class IX A student of SMPN 4 Kota Cirebon involving 3 level of students intentionally which has the ability of high, medium and low. At this stage, the evaluation is done to get information about the readability of the material, the material focus and attractiveness learning media products. As the result, the students were interested when teachers use Cirebonese language learning media. Students understand the usefulness of the learning media. Then students' readability level of the second quiz material is also very good.

\subsection{Small Group Evaluation Results}

In the third prototype evaluation of the student small group, 15 students were selected randomly from Class IX B SMPN 4 Kota Cirebon. This is carried out to investigate the effectiveness of instructional media used in the learning process. This learning process is performed in the real situation but with a fewer number of students. At this stage, the evaluation was the same as the evaluation of one to one in order to get information on the students' feedback about the legibility of the material, the focus of material and product attractiveness of the media. Based on the results obtained during the learning activity, the level of student motivation to learn by using instructional media indicate the average level with motivated category and the students are interested in the learning process.

\subsection{Field Trial Results}

Field trial phase (prototype 4) is the stage of the practicality which is conducted on students of class IX B SMPN 4 Kota Cirebon, with the number of 33 people per class. This trial used questionnaires pertaining to the assessment of students on 1) the quality of the learning media 2) the presentation of the material in the media and comments and suggestions related to the media. This is prepared to see the students' response to instructional media. The indicators are seen from the students'response and learning outcomes of the learning media. The test is administered in class IX B SMPN 4 Kota Cirebon on September 14th, 2015, with the following results such as it is attractive, nice or interesting (motivating)

The results of field trials become fundamental contribution for the improvement of instructional media. Finally, Cirebonese language learning media can be final product (final draft) after being revised which is feasible theoretically and empiricall.

Display learning multimedia of cirebonese language:
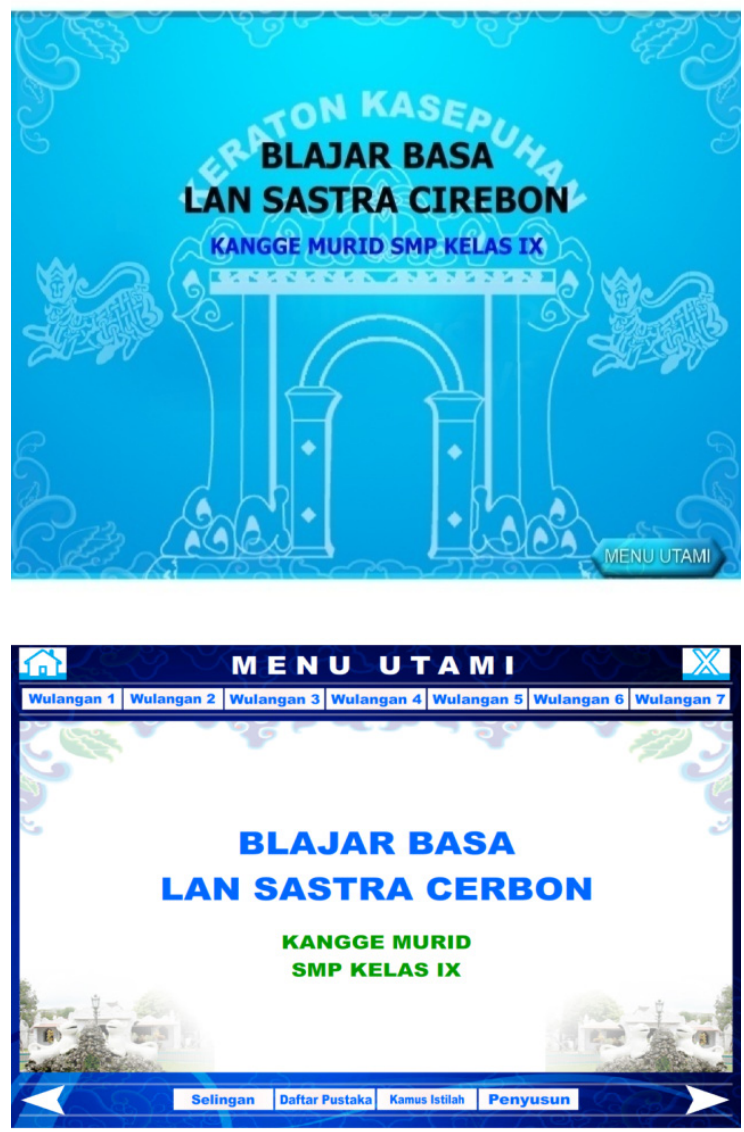


\section{Effectiveness Media}

\subsection{Test of the Effectiveness I}

To measure the effectiveness of Cireboneselanguage learning media program which has been developed, the authors perform the following steps:

\subsection{Conducting Pre- and Post-Test Test}

To determine the effectiveness of the program, pretests and final tests are conducted to see the extent to which the developed product can improve learning outcomes or achievement of learning objectives. The final test given to students after participating in learning activities is in the form of formative test. Its function is expected to obtain the data regarding developed language learning media program for Cirebonese subject.

\subsection{T- test}

Initial test scores and final tests of learning analyzed by paired T-test, refer to a design of experiments (one-group pretest-posttest design $\mathrm{O} X \mathrm{O}$ ). [9]. Because the T-test is one test of basic statistical inference in statistical analysis $t$ test assumptions include properties "robust" then, the assumptions of normality and homogeneity of variance might not be a serious problem (if neglected). Thus, it is assumed normal and homogenous population. [10].

$$
t=\frac{\overline{X_{1}}-\overline{X_{2}}}{\sqrt{\left(\frac{\Sigma x_{1}^{2}+\Sigma x_{2}^{2}}{n_{1}+n_{2}-2}\right)\left(\frac{1}{n_{1}}+\frac{1}{n_{2}}\right)}}
$$

\subsection{Effectiveness Test of Media Programs}

To determine the usefulness of the media program, the effectiveness test conducted. This test is in the form of the pretest and posttest which aims to determine the extent to which developed products can improve learning outcomes expected. The results of pre-tests and post-tests are described as follows: The data above is analyzed using ttest with the Microsoft Excel program and it shows in the following table:

Table 1. t-Test: Paired Two Sample for Means

\begin{tabular}{|c|c|c|}
\hline & Post- Test & Pre-Test \\
\hline Mean & 65,88235294 & 50,44117647 \\
\hline Variance & 53,74331551 & 50,557041 \\
\hline Observations & 34 & 34 \\
\hline Pearson Correlation & 0,733519027 & \\
\hline Hypothesized Mean Difference & 0 & \\
\hline Df & 33 & \\
\hline t Stat & 17,06730894 & \\
\hline $\mathrm{P}(\mathrm{T}<=\mathrm{t})$ one-tail & $\mathbf{3 , 0 5 6 9 E}-18$ & \\
\hline t Critical one-tail & 1,692360258 & \\
\hline $\mathrm{P}(\mathrm{T}<=\mathrm{t})$ two-tail & $6,1138 \mathrm{E}-18$ & \\
\hline $\mathrm{t}$ Critical two-tail & 2,034515287 & \\
\hline
\end{tabular}

t-table: 2.034515
Interpretation:

Based on the Table 1, it can be concluded that: First, Because t, 3,0569E-18 or $=3.0569 \times 10-18$ is smaller than $\mathrm{t}$ table at a significance level $(\alpha)$ amounted to 2.034515 0.05 , then it rejects $\mathrm{H} 0$ and accepts $\mathrm{Ha}$. It concluded that the Cireboneselanguage learning process using developed instructional media program is effective in improving students' learning outcomes. Second, mean scores after using Cirebonese language learning media is higher (better) than before using it. It is shown in the table Paired Sample Statistics, where the mean score before using amounted 50.44117647. While the mean score after using media language learning Cirebon amounted 65.88235294. This means that Cirebonese language learning media has a positive effect. Thirdly, Cirebonese language learning media program had a positive influence. Hence the decision to develop a media program on Cirebonese language subject has practical significance.

\section{Conclusion}

Therefore, the use of Cirebonese language learning media had a positive influence, then the decision to develop a media program for Cirebonese language learning media has practical significance.

\section{References}

[1] Heinrich, Robert, Michael Molenda, James Russel \& Sharone E. Smaldino. Instructional Media And Technologies For Learning. New York: Macmillan Publishing Company, 1996.

[2] Sadiman, Arif S. dkk. Media Pendidikan; Pengertian, Pengembangan dan Pemanfanfaatanya. Jakarta: CV. Rajawali, Pustekom Diknas, 1990.

[3] Munir. Multimedia: Konsep dan Aplikasinya Dalam Pendidikan. Bandung: Alfabeta, 2012.

[4] Famukhit, Muga Linggar, Maryono, Bambang Eka Purnama and Lies Yulianta (2013), Interactive Aplication Development Policy Object 3D Virtual Tour History Pacitan District Based Multimedia International Juornal Of Advanced Computer Science And Aplication (IJACSA), Vol.4 No.3.

[5] Vaughan, Tay. (2008). Multimedia: Making It Work, Seven Edition, New York: McGraw Hill.

[6] Mayer, Richard E. Multimedia Learning: Prinsip-Prinsip dan Aplikasi. terj. Teguh Wahyu Utomo, Yogyakarta: Pustaka Pelajar, 2009.

[7] Plomp, Tjeerd \& Donald P.Ely (ed), International Encyclopedia of Educational Technology-Second Edition. Cambridge: University Press, 1996.

[8] Suparman, Atwi, Desain Instruksional. Jakarta: Pusat Penerbitan Universitas Terbuka, 2004.

[9] Krathwohl, David R. Methods of Educational and Social Science Research: An Integrated Approach. Second Edition, New York: Longman, 1998.

[10] Leech, Nancy L, Karen C. Barrett and George A. Morgan. SPS for Intermediate Statistics: Use and Interpretation. Second Edition London: Lawrence Erlbaum Associates Publishers, 2005.

[11] Borg, W. R. \& Gall, M. D. Educational research: an introduction (7th ed.). New York: Longman, Inc, 2003.

[12] Carey, Dick, W, L. \& Carey, J. O. The systematic design of instruction. Boston: Harper Collin College Publisher, 2005. 